Historic, Archive Document

Do not assume content reflects current scientific knowledge, policies, or practices. 

An Inventory System for Multiple Use Evaluations

Peter F. Ffolliott

David P. Worley

U. S. Forest Service

Research Paper RM- 17

December 1965

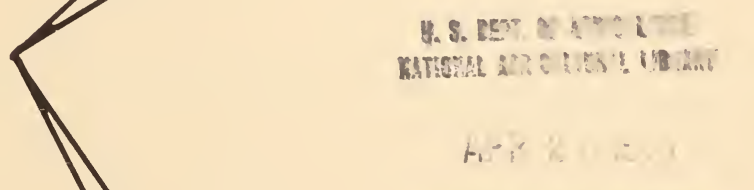

CURRENT SEGHL RECOAg

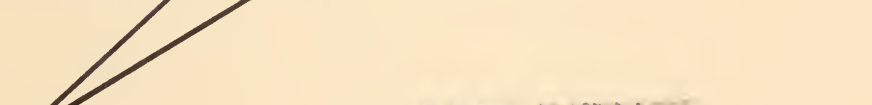

... 

AN INVENTORY SYSTEM FOR MULTIPLE USE EVALUATIONS

\author{
by \\ Peter F. Ffolliott, Associate Silviculturist \\ and \\ David P. Worley, Principal Economist
}

Rocky Mountain Forest and Range Experiment Station ${ }^{1}$

${ }^{1}$ Central headquarters maintained in cooperation with Colorado State University at Fort Collins; authors are located, respectively, at Flagstaff in cooperation with Arizona State College and at Tempe in cooperation with Arizona State University. 
Introduction

Description of method

Principles of method

Development of method

Basal area stocking levels

Procedure for tallying trees at a point

Sample design

Computations . • • • . • . • . • . • 44

Study area • • • • • • • • • • • • • • • 5

Proposed management system . . . . . . . 6

Determining management system feasibility • • • 8

Decision summary • • • • • • • • • • 8

Multiple use evaluation . • • • • • • • • • • 9

Watershed management . . . . . . . . . 9

Timber management • • • • • • • • • • • 9

Forest management--pathology . . . . . . . . 10

Range management . • • • • . • . . • • • . 11

Wildlife habitat management . . . . . . . . 11

Recreation management . • • • . • . • . 12

Cost of management change . . . . . . . . 13

A multiple use summary of the proposed

management system • • • • • • • • • • • 14

Literature cited . • • • • • • • • • • • • 14 


\title{
An Inventory System for Multiple Use Evaluations
}

\author{
by
}

Peter F. Ffolliott and David P. Worley

\section{INTRODUCTION}

The management of many tracts of forest land is based on principles of multiple use and sustained yield. Managers of such lands have available research results which show the product yields of the various multiple uses for different forest conditions and land productivity. More of this type of information is becoming available. This background data should help managers understand and evaluate proposed land management practices on their own lands in multiple use terms. Often, though, the research data are of limited use to managers because the land is not inventoried to take advantage of these findings in a variety of fields.

This paper describes a multiple BAF (basal area factor) inventory system that is flexible enough to describe a forested tract so multiple use interpretations can be made from known relations of product yields to the inventory description of the resources on the tract. Basal area was selected as the inventory basis because it is: (1) easily determined in the field; (2) easily converted to other expressions; and (3) many multiple use relations have already been developed with basal area as the independent variable. A multiple $\mathrm{BAF}$ system is a point-sampling system that uses several basal area factors to describe the stocking of trees. Its use is illustrated by hypothesizing forest management methods for one of the Beaver Creek pilot watersheds in Arizona. ${ }^{2}$

Known relations of different products to forest conditions are blended with inventory

${ }^{2} \mathrm{~A}$ 275,000-acre watershed on the Coconino National Forest where costs and benefits of intensive multiple-use land management are being evaluated as a part of the Arizona Watershed Program. data (1) to determine if it is feasible to manage the land as proposed; (2) to determine what changes in multiple use production can be expected; and (3) to estimate the immediate direct costs and returns associated with change in management.

\section{DESCRIPTION OF METHOD}

To be effective, an inventory must provide the land manager with information:

1. On the portions of an area stocked to different levels of stocking. Stocking, as used here, is a measure of occupancy of growing space by different classes of trees.

2. On the portions of an area stocked with trees exhibiting specific characteristics. These tree characteristics must be related to different parameters required in multiple use evaluation.

3. On the feasibility of treating an area to attain desired stocking conditions specified by multiple use objectives. The land manager must be able to determine whether it is rational to put a particular treatment on an area.

4. For describing the overstories on different areas on a standardized basis.

\section{Principles of Method}

In essence, the inventory method involves point-sampling techniques. Points are considered either not stocked or stocked to a particular basal area level. If no trees are recorded, a point is not stocked at the given basal area level. A point is stocked at the given basal area level if at least one tree is tallied. 
Point samples are located on an area to give a "representative" sample. Each point is described as not stocked or stocked to each at several basal area stocking levels. The number of points that are stocked to a given level can be determined and expressed as a percent of the total number of point samples on an area. The percent of the area stocked, or not stocked, can be determined by any sampling method that provides a representative sample of the area.

The relationship between stocking at different basal area levels is found by using more than one BAF to determine stocking at a point. Stocking conditions on an area can then be expressed in terms of percent of the area not stocked or stocked to different basal area stocking levels. It is then possible to decide on the feasibility of carrying out a particular type of management. For example, the stocking conditions at 50 square feet basal area stocking level on an area could be not stocked, 15 percent of the area; stocked, 85 percent of the area. A proposed management prescription could be to thin the overstory to 50 square feet basal area. What percent of the area will meet management specifications following treatment?

Since 85 percent of the area is stocked at a basal area level of 50 square feet, this will be the percent of the area that will meet management specifications. The 15 percent not stocked at 50 square feet will not meet the stocking requirements outlined in the prescription.

The presence or absence of specific characteristics are recorded for the trees tallied at the point samples. The occurrence of a particular characteristic is then determined within an area, and allows for describing the percent of an area not stocked or stocked with trees exhibiting this characteristic at different basal area stocking levels.

\section{Development of Method}

An overstory inventory based on the principles discussed above was developed to meet the particular stocking conditions on Beaver Creek. The overstory on Beaver Creek can be described as "cutover" ponderosa pine with intermingling Gambel oak and alligator juniper. All size classes are included. The adaptation of the method as applied to Beaver Creek was designed to measure these conditions specifically.

\section{Basal Area Stocking Levels}

The basal area stocking levels used in this inventory were 25, 50, and 75 square feet. These basal area levels appeared to be rational levels for management on Beaver Creek. Two approaches were followed to determine if a point is not stocked or stocked for each of the basal area stocking levels.

An angle gage was used to tally trees 7.0 inches d.b.h. and larger. The BAFs used were 25,50 , and 75 , corresponding to the three basal area stocking levels. A point was not stocked at a basal area level of 25 square feet with trees 7.0 inches d.b.h. and larger if no trees of this size were tallied with the angle gage at a BAF of 25. A point was stocked at a basal area level of 75 square feet if at least one tree was tallied with the angle gage at a BAF of 75 .

The smaller size classes in ponderosa pine occur in clumps. Existing basal area levels under these conditions are not desirable. Therefore, fixed-size plots were used for tallying trees smaller than 7 inches d.b.h. The size of these plots was determined from growing-space requirements for the number of trees per acre necessary to attain the basal area when the stand reaches 10 inches d.b.h. These data are based on proposed ponderosa pine stand structures necessary to sustain production at different basal area levels when the stand reaches 10 inches d.b.h. (table 1).

Three fixed-size plots for each basal area level were used to simplify field measurements. The three plots included a plot for the small pole size class ( 4 to 6 inches d.b.h.), the sapling size class ( 1 to 3 inches d.b.h.), and reproduction (1 to $4-1 / 2$ feet in height).

It was necessary to determine the average number of trees per acre needed in a size 
Table 1.--Stand structures to sustain production at different prospective basal area levels

\begin{tabular}{|c|c|c|c|c|c|c|}
\hline \multirow{3}{*}{$\begin{array}{c}\text { Diameter } \\
\text { breast } \\
\text { height } \\
\text { (inches) }\end{array}$} & \multicolumn{6}{|c|}{ Basal area level of -- } \\
\hline & \multicolumn{2}{|c|}{$\begin{array}{l}25 \text { square feet } \\
\text { per acre }\end{array}$} & \multicolumn{2}{|c|}{$\begin{array}{c}50 \text { square feet } \\
\text { peracre }\end{array}$} & \multicolumn{2}{|c|}{$\begin{array}{c}75 \text { square feet } \\
\text { per acre }\end{array}$} \\
\hline & $\begin{array}{c}\text { Trees } \\
\text { per acre }\end{array}$ & $\begin{array}{c}\text { Basal } \\
\text { area }\end{array}$ & $\begin{array}{c}\text { Trees } \\
\text { per acre }\end{array}$ & $\begin{array}{c}\text { Basal } \\
\text { area }\end{array}$ & $\begin{array}{c}\text { Trees } \\
\text { per acre }\end{array}$ & $\begin{array}{l}\text { Basal } \\
\text { area }\end{array}$ \\
\hline & No. & Sq.ft. & No. & Sq.ft. & No. & Sq. ft. \\
\hline 1 & 208 & 1.64 & 415 & 2.26 & 623 & 3.12 \\
\hline 2 & 175 & 3.85 & 350 & 7.64 & 525 & 11.55 \\
\hline 3 & 150 & 7.35 & 300 & 14.73 & 450 & 22.05 \\
\hline 4 & 126 & 10.96 & 252 & 22 & 378 & 33 \\
\hline 5 & 106 & 14 & 213 & 29 & 319 & 43 \\
\hline 6 & 92 & 18 & 183 & 36 & 275 & 53 \\
\hline 7 & 76 & 20 & 153 & 41 & 229 & 61 \\
\hline 8 & 66 & 22 & 132 & 46 & 198 & 68 \\
\hline 9 & 55 & 24 & 111 & 49 & 167 & 74 \\
\hline 10 & 46 & 25 & 92 & 50 & 138 & 75 \\
\hline
\end{tabular}

${ }^{1}$ Adapted from Myers, Clifford A., Methods of cutting ponder osa pine in the Southwest. 29 pp., App. I-IV. (Study plan on Timber Management Project FS-RM-1203.10, submitted June 20, 1961; on file at Rocky Mountain Forest \& Range

Exp. Sta., U.S. Forest Serv., Ft. Collins, Colo.)

class to compute the radius of the fixed-size plots. The average was obtained by totaling the number of trees in each d.b.h. class represented in the size class (table 1), and dividing by the number of d.b.h. classes in the size class. The computations are summarized in table 2.

It is important to remember that stocking by these smaller size classes is to a "prospective" basal area level. "Prospective" stocking will become existing stocking when

Table 2.--Determination of plot radius for the fixed-size plots

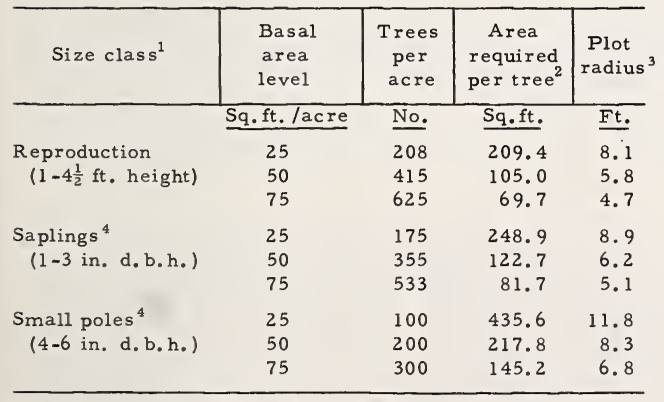

${ }^{1}$ Refers to diameter range; not to specific products.

${ }^{2} 43,560$ divided by number of trees per acre.

$$
\sqrt{\frac{\text { Area pertree }}{3.1416}}
$$

${ }^{4}$ Saplings measured by 1 -inch classes; poles and sawtimber, by 2 -inch classes. the stands reach 10 inches d.b.h. if the stands on Beaver Creek are placed under management as prescribed by the proposed stand structures.

The procedure followed in determining whether a point is not stocked or stocked to a "prospective" basal area level was similar to the angle gage tally. A point was not stocked with small poles at a "prospective" basal area level of 25 square feet if no small poles were counted in the appropriate fixed-size plot. A point was stocked with saplings at a "prospective" basal area level of 75 if at least one sapling was tallied in the proper fixed-size plot.

\section{Procedure for Tallying Trees at a Point}

The procedure followed in tallying trees at a point is summarized by the following steps:

1. Tally trees stocking a point to a basal area level of 25 square feet. Tree number 1 will be the first tree tallied; tree number 2 the second tallied, etc.

a. Count all trees 7 inches d.b.h. and above with the angle gage at a BAF of 25. Tally in a fixed pattern, to be carried out on all points.

b. Count the small poles on the appropriate fixed-size plot.

c. Count all saplings.

d. Count all reproduction.

2. Tally trees stocking a point to a basal area level of 50 square feet. These trees will already be tallied for the 25-square-foot level.

3. Tally trees stocking a point to a basal area level of 75 square feet. These trees will have been tallied above.

Individual measurements were made on the trees tallied to determine stocking to a basal area level of 25 square feet. To eliminate bias, specific trees were selected in advance for measuring total height and annual ring count. The measurements made in this inventory were of particular interest on Beaver Creek since it was desired to determine treatment feasibility and timber values. Many 
additional measurements could have been included if desired.

The individual tree measurements made are listed below:

1. Species.

2. D.b.h.

3. Total height--taken on only the first tree tallied to determine stocking to a basal area level of 25 square feet.

4. Annual ring count--increment boring made on same tree measured for total height.

5. Crown position.

6. Biotic injury:
a. Dwarfmistletoe.
b. Insect damage.
c. Disease damage.

7. Mechanical injury:
a. Fire scars.
b. Lightning scars.
c. Damaged top--broken, dead, etc.

8. Form characteristics:
a. Sweep.
b. Crook.
c. Lean.
d. Fork.

9. Knot configurations:

a. Number of clear faces.

b. Number of knots.

c. Size of knots.

Points were considered not stocked to a basal area level if no trees were tallied at the point by means of the corresponding basal area measurements. A point not stocked was recorded as (a) can be stocked naturally or artificially, or (b) cannot be stocked naturally or artificially (rocks, water, etc.). These latter points were considered "nonstockable."

Topographic information was also taken during the inventory. The aspect and slope percent were measured at each point. The area sampled can be characterized by steepness and aspect relations from these measurements.

\section{Sample Design}

An important requirement in sample design is that a "representative" sample be obtained. A systematic sample design may be used, or, if measurements of variation are wanted, a systematic sample with multiple random starts (Freese 1962, Shiue 1960) ${ }^{3}$ can be followed.

The point samples should be located at regular intervals along lines running across the area sampled, regardless of the sample design applied. This is important because many of the characteristics tallied can be mapped, and a regular pattern facilitates mapping. The interval between point samples and the number of lines depends on the intensity of sampling desired.

\section{Computations}

Individual point samples are described in terms of each basal area stocking level as follows:

1. Not stocked.

2. Stocked.

3. If not stocked:

a. Can be stocked naturally or artificially.

b. Cannot be stocked naturally or artificially。

If each point sample is considered as a sample unit, the area inventoried can be described as follows:

1. Percent of the area not stocked at each basal area level.

2. Percent of the area stocked.

If an area is stocked at a particular basal area level, trees exhibiting different individual characteristics can be segregated. Then, the percent of the area stocked at the basal area level by trees of different characteristics can be determined.

The relationships between the percent of the area not stocked and stocked at the three basal area levels are determined. These relationships can be represented by regressions, and the equations for the regressions considered stocking equations. It is possible to

\footnotetext{
${ }^{3}$ Nomes and dates in parentheses refer to Literature Cited, p. 14.
} 
determine the percent of the area not stocked or stocked at basal area levels between those used in the inventory from these stocking equations.

Linear regressions were developed from the three BAFs used in this inventory. Regressions for particular size classes, or for BAFs near the extremes for the whole populations, may require a curvilinear form. BAFs would have to be used to develop the proper form of the relationship.

The following stocking equation describes the percent of the area not stocked with ponderosa pine (all size classes):

$$
\begin{aligned}
\mathrm{Y}= & -5.0+0.4 \mathrm{X} \\
\mathrm{Y}= & \text { percent of area not stocked with pon- } \\
& \text { derosa pine } \\
\mathrm{X}= & \text { any basal area level between } 25 \text { and } 75 \\
& \text { square feet }
\end{aligned}
$$

What percent of the area is not stocked with ponderosa pine at 40 square feet basal area?

$$
\begin{aligned}
& \mathrm{Y}=-5.0+0.4(40) \\
& \mathrm{Y}=11 \text { percent }
\end{aligned}
$$

The following stocking equation represents the percent of the area stocked $(\mathrm{Y})$ with ponderosa pine sawtimber (11.0 inches and larger).

$$
\mathrm{Y}=93.2-0.8 \mathrm{X}
$$

What is the percent of area stocked with ponderosa pine sawtimber at 65 square feet?

$$
\begin{aligned}
& \mathrm{Y}=93.2-0.8(65) \\
& \mathrm{Y}=41 \text { percent }
\end{aligned}
$$

The examples illustrate use of stocking equations to determine stocking conditions by a species or a size class. Stocking equations can also be developed to express stocking conditions by trees exhibiting any of the other characteristics measured in this inventory.

Stand tables are also developed from the inventory. Stand tables describe the abundance of growing stock on an area by species and size class. They are also necessary for determining growth by a stand projection method. ${ }^{4}$

Point sampling, with any of the three BAFs, has proved satisfactory for constructing stand tables from the inventory data on the larger d.b.h. classes (7.0 inches d.b.h.). A strip cruise with narrow strips was used to develop stand tables in the smaller size classes, however, because of the clumped pattern of distribution. Stand tables may possibly be developed for all size classes from pointsampling techniques in forests with more uniform distribution in these smaller size classes.

\section{STUDY AREA}

The overstory inventory was field tested on a 450-acre study area on the Beaver Creek pilot watersheds.

Timber was last cut in a period from 194350 , and half of the estimated merchantable sawtimber volume was removed. There has been no cutting since 1950 .

Numbers of trees per acre, basal area per acre, and volume per acre were inventoried for each species on an area. These data are given for ponderosa pine, Gambel oak, and alligator juniper in table 3 .

The soils are derived from basalt parent material. Soil management areas on the watershed are Siesta-Sponseller, a "high" timber producer, 5 and Stoneman, a "medium" producer. ${ }^{5}$

${ }^{4}$ The stand projection method of growth determination used with this inventory was described by Hasel, A. A. A design for multipurpose forest surveys of large areas. 51 pp. (Unpublished manuscript on file in the U.S. Forest Service office, Washington, D. C.). Ffolliott (1965) shows how Hasel's method was applied in Arizona.

5Terms used to describe soil management area timber potentials, in Anderson, T. C., Jr., Williams, J.A., and Crezee, D. B. Soil management report for Beaver Creek watersheds of Coconino National Forest, Region 3.66 pp., illus. 1960. (Mimeographed report on file at Region 3 office, U. S. Forest Serv., Albuquerque, N. Mex.) 
Table 3. --Number of trees, basal area, and volumes per acre for ponderosa pine, Gambel oak, and alligator juniper on study area

\begin{tabular}{|c|c|c|c|c|c|c|c|c|c|}
\hline \multirow{2}{*}{ Size class $^{1}$} & \multicolumn{3}{|c|}{ Ponderosa pine } & \multicolumn{3}{|c|}{ Gambel oak } & \multicolumn{3}{|c|}{ Alligator juniper } \\
\hline & Trees & Basal area & Volume $e^{2}$ & Trees & Basal area & Volume ${ }^{3}$ & Trees & Basal area & Volume $e^{4}$ \\
\hline & No. & Sq.ft. & Cu.ft. & No. & Sq.ft. & Cu.ft. & No. & Sq.ft. & Cu.ft. \\
\hline $\begin{array}{l}\text { Reproduction } \\
\left(1-4 \frac{1}{2} \mathrm{ft} \text {. height }\right)\end{array}$ & 245 & -- & -- & -- & -- & -- & 17.3 & -- & -- \\
\hline $\begin{array}{l}\text { Saplings } 5 \\
\qquad(1-3 \text { in. d.b.h.) }\end{array}$ & 635 & 14.0 & 476 & 81.4 & 1.8 & 24.4 & 28.5 & 0.6 & 2.8 \\
\hline $\begin{array}{l}\text { Poles }^{5} \\
\qquad(4-10 \text { in. d.b.h. })\end{array}$ & 166 & 31.0 & 488 & 39.0 & 7.5 & 89.3 & 7.1 & .9 & 12.1 \\
\hline $\begin{array}{l}\text { Sawtimber }{ }^{5} \\
\qquad(12 \text { in. d.b.h. and larger) }\end{array}$ & 18.2 & 32.0 & 794 & 4.6 & 5.0 & 84.0 & 2.6 & 11.9 & 94.8 \\
\hline Total & $1,064.2$ & 77.0 & 1,758 & 125.0 & 14.3 & 197.7 & 55.5 & 13.4 & 109.7 \\
\hline
\end{tabular}

${ }^{1}$ Refers to diameter range; not to specific products.

${ }^{2}$ Basis: Myers (1963).

${ }^{3}$ Basis: Gevorkiantz and Olsen (1955).

\section{PROPOSED MANAGEMENT SYSTEM}

A management system is proposed for the study area to illustrate the use and the flexibility of the multiple BAF inventory. It was not designed to satisfy any particular management objective, only to model the inventory system.

Certain portions of the study area (fig. 1) are to be managed to produce four even-aged stand conditions in strips approximately 200 feet wide, shown schematically in figure 2. The area is to be managed on a 100-year rotation. The most practical of two courses of action will be followed in this conversion.

1. Immediate conversion system--The desired profile can be produced immediately if the spatial distribution of tree sizes permits 50 percent of each timbered strip to be stocked to 50 square feet basal area with the desired tree sizes (fig. 2a). Cleared strips will be planted with ponderosa pine. All alligator juniper and Gambel oak will be eliminated from the areas as they are cleared. All trees larger than called for on the timbered strips will be cut. Subsequent cuts to sustain the management pattern, the first of which will occur in 25 years on the large and medium saw-

Figure 1.--Study area showing proposed management system.
${ }^{4}$ Basis: Extension and modification from Howell and Lexen (1939).

${ }^{5}$ Saplings measured by 1 -inch classes; poles and sawtimber, by 2 -inch classes.

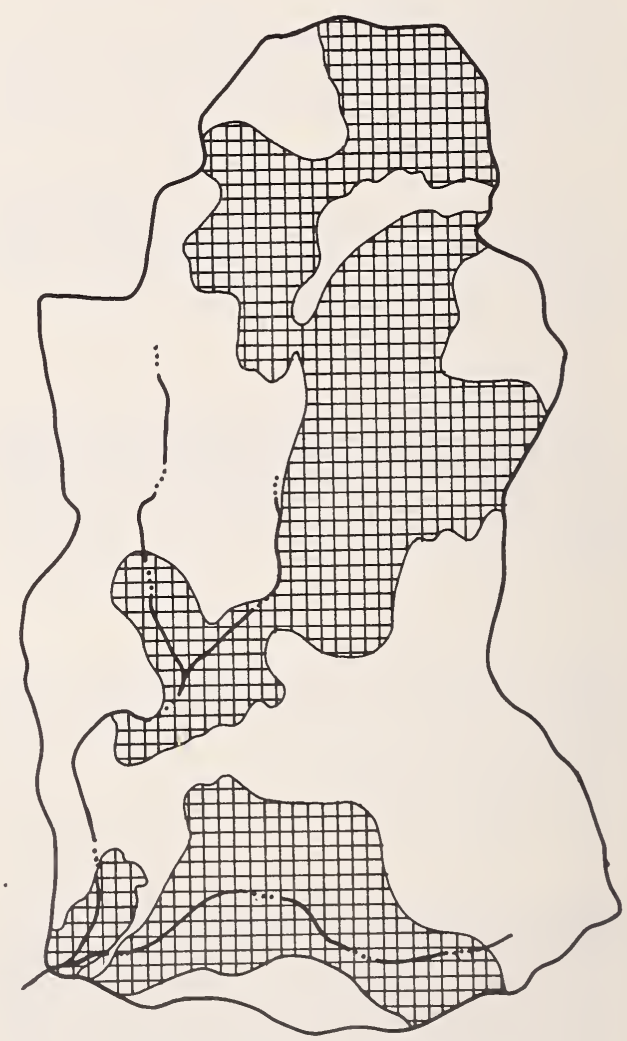

- Even-Aged management area -UNEVEN-AGED MANAGEMENT AREA TOTAL AREA $=450$ ACRES 

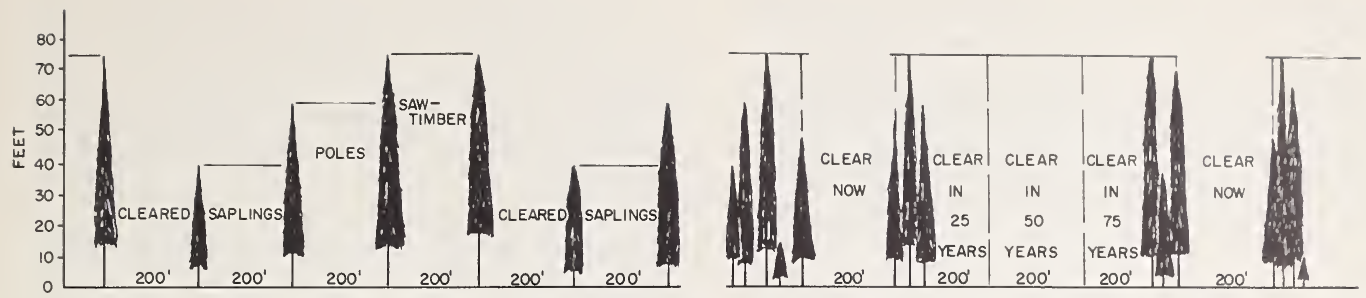

FIGURE 2

a. This schematic diagrom izlustrates the even-aged profile desired. Can this profize be produced immediately?

timber strip, will clear this area for planting. The area cleared now will then be the sapling size class.

2. Long-term conversion system.--If the timber overstory does not meet the criteria set forth for the immediate conversion system, the three timbered strips in that system ( 600 feet wide) will be left in their existing condition provided 50 percent of the area is covered with 75 square feet basal area in trees of all sizes. The conversion process will continue by clearing successive 200-foot strips at 25-year intervals (fig. 2b). Gambel oak and alligator juniper will be removed from the cleared areas but retained on uncleared areas as before.

The ponderosa pine on the remainder of the study area is to be managed by the group selection system along an uneven-aged management regulation system. The growing stock level for uneven-aged management must be compatible with a " $q$ " 6 of 1.49 , ascertained for the Fort Valley Experimental Forest, ${ }^{7}$ at

" " $q$ " is defined as the average quotient between numbers of trees in consecutively smaller 2-inch d.b.h. classes (Myers 1962).

${ }^{7}$ Myers, C. A. Methods of cutting ponderosa pine in the southwest. $29 \mathrm{pp}$. (Study plan on Timber Management Project FS-RM-1203.10, submitted June 20, 1961; on file at Rocky Mountain Forest \& Range Exp. Sta.,U. S. Forest Serv., Ft. Colzins, Colo.) b. Perhaps existing timber stocking conditions require slow conversion by clearing successive strips every 25 years as ilzustrated here.

a practical level made possible by existing stocking. A graph of existing stocking and a proposed stocking level of 40 square feet per acre is shown in figure 3 . The alligator juniper components of the overstory are to be eliminated, and the Gambel oak is to be retained for mast production.

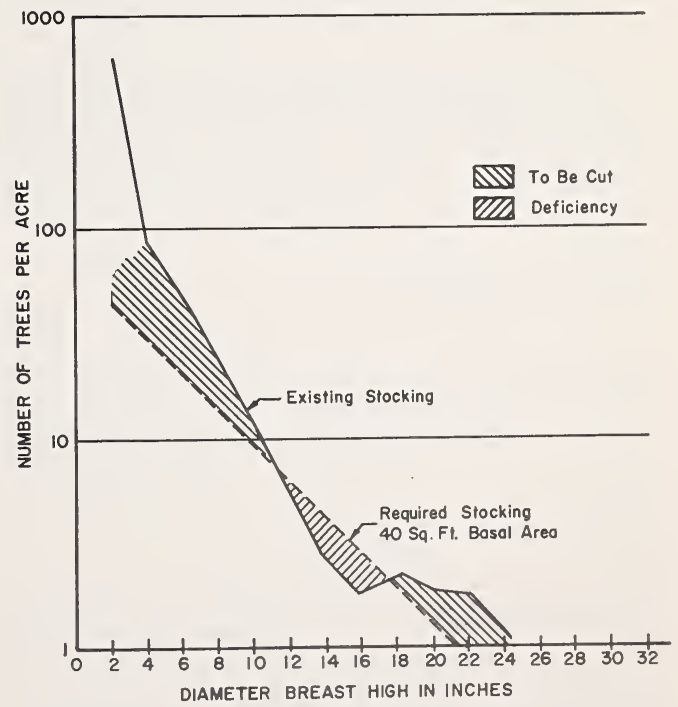

Figure 3.--Tree size distribution on uneven-aged management area. 
Determining Management System Feasibility

The immediate problem is to determine whether the overstory is compatible with the proposed management system. The first specific question arises as to the steps to take to convert the designated area to even-aged conditions. The overstory is tested to see if immediate conversion to the strip pattern is feasible. Table 4 shows that less than 50 percent of the medium sawtimber and large pole strips meet the 50-square-foot basal area criteria. Only 40 percent and 30 percent, respectively, are stocked with those size classes now, so posttreatment stocking could be no better.

Table 4. --Proportion of a rea stocked with ponderosa pine of different size classes on even-aged portion of study area (based on stocking equation developed from inventory)

\begin{tabular}{|c|c|c|c|}
\hline \multirow[b]{2}{*}{ Size class on strip } & \multirow[b]{2}{*}{ Stocking level } & \multicolumn{2}{|c|}{ Proportion of area } \\
\hline & & $\begin{array}{c}\text { Not } \\
\text { stocked }\end{array}$ & Stocked \\
\hline & Sq.ft. basal area & $\mathrm{Pe}$ & ccent \\
\hline \multicolumn{4}{|l|}{ Medium and } \\
\hline large sawtimber & 50 & 60 & 40 \\
\hline \multicolumn{4}{|l|}{ Large poles and } \\
\hline small sawtimber & 50 & 70 & 30 \\
\hline \multicolumn{4}{|l|}{ Small poles and } \\
\hline saplings & 50 & 30 & 70 \\
\hline
\end{tabular}

The stocking equation for ponderosa pine of all sizes combined shows that leaving the uncut strips in their existing condition will result in 80 percent of this area being stocked to the 75-square-foot criteria with trees of all sizes. Thus the long-range conversion system is feasible.

The remainder of the study area is to be managed by the group selection system. It must be determined whether this is feasible, and how long it will take to achieve a balanced distribution of size classes. The existing and required tree size distributions to achieve this balance at a 40-square-foot per acre basal area level are shown in figure 3 . The trees represented by the area between the two lines when the existing distribution exceeds the required distribution would be cut. Slight deficiencies are present in the 14- and 16-inch diameter classes. Based on existing growth rates, a 30-year adjustment period will be required for the deficiency to be made up.
The existing size class distribution must be intermingled to manage this part of the study area by an uneven-aged system. The amount of intermingling can be determined by means of the stocking equations developed from the inventory.

The stocking equation shows that 13 percent of the watershed to be managed by an unevenaged system is not stocked at a basal area level of 40 square feet per acre, the proposed management level. The intermingling of size classes on the area adequately stocked at 40 square feet per acre is illustrated in table 5 . It should be noted that portions of this area are supporting three or more size classes. These are included in table 5 in order to show all the marking options open to produce the intermingling of size classes needed in uneven-aged management.

Table 5. --Intermingling of size classes on area stocked at basal area level of 40 square feet per acre

\begin{tabular}{|c|c|c|c|c|}
\hline Size class & $\begin{array}{l}\text { Saw- } \\
\text { timber }\end{array}$ & Poles $^{1}$ & Saplings ${ }^{1}$ & $\begin{array}{l}\text { Repro- } \\
\text { duction }\end{array}$ \\
\hline $\begin{array}{l}\text { Sawtimber }{ }^{1} \\
(12 \text { in. d. b.h. } \\
\text { and larger })\end{array}$ & $-\cdots$ & Percer & of area & --- \\
\hline $\begin{array}{l}\text { Poles } \\
\quad(4-10 \text { in. d. b.h.) } \\
\text { Saplings }{ }^{1}\end{array}$ & 23.5 & 14.0 & & \\
\hline $\begin{array}{l}\quad(1-3 \text { in. d. b.h. }) \\
\text { Reproduction }\end{array}$ & 24.0 & 40.0 & 3.5 & \\
\hline (1 $-4 \frac{1}{2} \mathrm{ft}$. height) & 23.5 & 30.0 & 38.5 & 5.0 \\
\hline
\end{tabular}

${ }^{1}$ Saplings measured by 1 -inch classes; poles and sawtimber, by 2 -inch classes.

\section{Decision Summary}

The findings are summarized as follows:

1. Conversion of this study area to even-aged strips will have to follow the long-term conversion system of clearing and planting successive strips every 25 years. The stocking by size classes in the uncut area is inadequate for immediate conversion.

2. The remainder of the study area can be managed according to the group selection form of uneven-aged management as prescribed at a level of 40 square feet per acre basal area. 


\section{MULTIPLE USE EVALUATION}

For multiple use evaluation, the inventory must provide the information required so that specialists can determine the effects of a particular course of management on production in their specialties. / Specific questions are posed about various uses and are answered for this study area by combining research results in these fields with inventory data. The inventory provides explicit data about trees and stands and their distribution for existing conditions, and provides a basis for estimating answers to the same questions after management is changed.

\section{Watershed Management}

\section{Statement of Concern}

While strip cuttings as proposed for the even-aged management portion of the study area have not been tried in the ponderosa pine type in the Southwest, this type of cutting has been an effective means of increasing streamflow in other forest types (Anderson and Gleason 1959, Hoover 1960). For demonstration purposes, it is assumed that strip cutting would be most effective where stands are dense and slopes 10 percent or greater.

\section{Problem}

Are the proposed strip cuttings located where the ponderosa pine is densest and on the steepest part of the study area?

\section{Solution}

Solve the stocking equation for ponderosa pine for a relatively high level of stocking to

Table 6.--Proportion of study area not stocked and stocked with ponderosa pine at basal area level of 75 square feet per acre

\begin{tabular}{l|c|c|c}
\hline $\begin{array}{c}\text { Proportion of } \\
\text { study area }\end{array}$ & Total area & $\begin{array}{c}\text { Even-aged } \\
\text { portion }\end{array}$ & $\begin{array}{c}\text { Uneven-aged } \\
\text { portion }\end{array}$ \\
\hline & \multicolumn{3}{|c|}{ Percent of area } \\
Not stocked & 30 & 20 & 40 \\
Stocked & 70 & 80 & 60 \\
\hline
\end{tabular}

determine the proportion of the area stocked and overstocked at this level. The results for a 75-square-foot basal area level appear in table 6. Summarize the slope percents on each area to determine if they are steeper on the even-aged part than on the uneven-aged part (table 7).

Table 7.--Proportion of study area by slope percentages

\begin{tabular}{c|c|c|c}
\hline $\begin{array}{c}\text { Proportion of } \\
\text { study area }\end{array}$ & Total area & $\begin{array}{c}\text { Even-aged } \\
\text { portion }\end{array}$ & $\begin{array}{c}\text { Uneven-aged } \\
\text { portion }\end{array}$ \\
\hline \multicolumn{3}{|c|}{ Percent of area } \\
\hline
\end{tabular}

Slope percentage:

\begin{tabular}{rrrr}
0 & 4 & 1 & 6 \\
5 & 31 & 18 & 45 \\
10 & 32 & 38 \\
15 & 27 & 16 \\
20 & 5 & 7 & 3 \\
25 & 2 & 1 & 2 \\
30 & 1 & 1 & 0 \\
35 & 0 & 0 & 0 \\
40 & 1 & 0 & 1 \\
\hline
\end{tabular}

\section{Conclusions}

Eighty percent of the even-aged area is adequately stocked with ponderosa pine at a basal area level of 75 square feet per acre, while only 60 percent of the uneven-aged portion is thus stocked. Eighty-one percent of the even-aged portion is on slopes 10 percent or greater, while only 49 percent of the unevenaged portion is this steep.

It is concluded that the even-aged portion of the study area is better suited for strip cutting to increase water yield than is the uneven-aged portion. Current streamflow records for this area show water yield to be 3.4 inches; the management change can be expected to increase this yield.

\section{Timber Management}

\section{Statement of Concern}

Reduction in timber stocking often immediately decreases timber growth per acre. Individual tree growth may increase, however, so that eventually timber growth per acre may increase. 
Problem

Determine present ponderosa pine growth per acre, and show how this growth will be affected immediately following and 5 years after the management change.

\section{Solution}

Apply a stand projection method of growth determination to the stand tables and diameter growth data from the inventory. Required of the inventory are (1) pretreatment stand table and diameter growth for pretreatment growth determination; (2) posttreatment stand table to use with existing diameter growth to determine immediate growth response; and (3) a projection of expected diameter growth to use with the posttreatment stand table to estimate growth some years hence. Data for (1) and (2) are available from the inventory, while data for (3) will require research results on changes in diameter growth with time. The calculations are summarized in table 8 .

Table 8.--Pretreatment and posttreatment growth rates ${ }^{1}$ on study area

\begin{tabular}{|c|c|c|c|}
\hline \multirow{2}{*}{ Size class ${ }^{2}$} & \multirow{2}{*}{$\begin{array}{c}\text { Pre- } \\
\text { treatment }\end{array}$} & \multicolumn{2}{|c|}{ Posttreatment } \\
\hline & & Immediate & 5 years $^{3}$ \\
\hline & \multicolumn{3}{|c|}{ Cubic feet per acre per year } \\
\hline $\begin{array}{l}\text { Poles }^{4} \\
\qquad(4-10 \text { in. d. b. h. })\end{array}$ & 22.9 & 10.0 & 12.3 \\
\hline $\begin{array}{l}\text { Sawtimber } \\
\qquad 12 \text { in. d.b.h. and larger) }\end{array}$ & 10.6 & 8.3 & 12.5 \\
\hline Total & 33.5 & 18.3 & 24.8 \\
\hline
\end{tabular}

${ }^{1}$ Difference between ingrowth and outgrowth in a diameter

class. Basis: Myers (1963).

${ }^{2}$ Refers to diameter range; not to specific products.

${ }^{3} \mathrm{Growth}$ based on preliminary analysis of data from already thinned areas on Beaver Creek.

${ }^{4}$ Measured by 2 -inch classes.

\section{Conclusions}

1. Current growth amounts to about 33.5 cubic feet per acre per year.

2. Growth immediately after the management change is expected to be 55 percent of pretreatment growth, or 18.3 cubic feet per acre per year.
3. Growth 5 years after management change should amount to 74 percent of the current growth, or 24.8 cubic feet per acre per year.

4. Sawtimber growth after 5 years is estimated at 118 percent (18 percent increase) of current sawtimber growth.

\section{Forest Management--Pathology}

\section{Statement of Concern}

The importance of dwarfmistletoe in southwestern ponderosa pine is well known (Hawksworth 1961). The parasite both increases mortality and reduces host vigor.

\section{Problem}

What is the current incidence of dwarfmistletoe by size class on the study area? Can this be reduced immediately by the change in management?

Solution

Stand tables of all trees and of dwarfmistletoed trees, constructed from the inventory, show the current status of dwarfmistletoe incidence. Both management areas were test marked according to the prescription for the new management system, and similar stand tables for the new management were calculated. These data are summarized in table 9 .

\section{Conclusions}

1. The current incidence of dwarfmistletoe is estimated at 8.3 percent of the total trees.

2. This incidence will remain essentially unchanged on the even-aged area.

3. Dwarfmistletoe can be eliminated from the remainder of the study area.

4. The incidence of dwarfmistletoe on the study area as a whole will be reduced about 50 percent. 
Table 9. --Pretreatment and posttreatment incidence of dwarfmistletoe on study area

\begin{tabular}{|c|c|c|c|c|c|c|c|c|}
\hline \multirow{3}{*}{ Size class ${ }^{1}$} & \multicolumn{2}{|c|}{ Pretreatment } & \multicolumn{6}{|c|}{ Posttreatment } \\
\hline & \multirow{2}{*}{$\begin{array}{c}\text { Total } \\
\text { trees } \\
\text { per acre }\end{array}$} & \multirow{2}{*}{$\begin{array}{l}\text { Dwarf- } \\
\text { mistletoe } \\
\text { infected }\end{array}$} & \multicolumn{2}{|c|}{ Even-aged management } & \multicolumn{2}{|c|}{ Uneven-aged management } & \multicolumn{2}{|c|}{ Total } \\
\hline & & & $\begin{array}{c}\text { Total } \\
\text { trees } \\
\text { per acre }\end{array}$ & $\begin{array}{c}\text { Dwarf- } \\
\text { mistletoe } \\
\text { infected } \\
\end{array}$ & $\begin{array}{l}\text { Total } \\
\text { trees } \\
\text { per acre } \\
\end{array}$ & $\begin{array}{c}\text { Dwarf- } \\
\text { mistletoe } \\
\text { infected }\end{array}$ & $\begin{array}{c}\text { Total } \\
\text { trees } \\
\text { per acre }\end{array}$ & $\begin{array}{l}\text { Dwarf- } \\
\text { mistletoe } \\
\text { infected }\end{array}$ \\
\hline & Number & Percent & Number & Percent & Number & Percent & Number & Percent \\
\hline $\begin{array}{l}\text { Poles }{ }^{2} \\
\qquad(8-10 \text { in. d. b.h. })\end{array}$ & 40.6 & 6.3 & 31.1 & 7.0 & 22.4 & 0 & 25.9 & 3.7 \\
\hline $\begin{array}{l}\text { Sawtimber }{ }^{2} \\
\qquad(12 \text { in. d.b.h. and larger) }\end{array}$ & 19.7 & 12.5 & 15.6 & 10.9 & 14.6 & 0 & 15.0 & 5.1 \\
\hline Total & 60.3 & 8.3 & 46.7 & 8.3 & 37.0 & 0 & 40.9 & 4.1 \\
\hline
\end{tabular}

${ }^{1}$ Refers to diameter range; not to specific products.

${ }^{2}$ Measured by 2 -inch classes.

\section{Range Management}

\section{Statement of Concern}

Livestock carrying capacity largely depends upon herbage production, which in turn is affected by the amount of tree cover. Herbage production decreases as basal area increases (Pase 1958).

\section{Problem}

Estimate existing herbage production, and show how the prescribed management may change production by applying the Pase (1958) equation as adjusted to Beaver Creek to appropriate basal area levels determined from the inventory.

Solution

The production equation adjusted for Beaver Creek is logarithm $\mathrm{Y}=2.949-0.0096 \mathrm{X}$, where $\mathrm{Y}$ is herbage production and $\mathrm{X}$ is basal area. This adjustment works well for the basal area levels included in the inventory. Cleared areas produce an average of 950 pounds per acre. ${ }^{8}$ This production will apply to areas cleared to make the change to evenaged management.

${ }^{8}$ Based on unpublished data from a range production study on Beaver Creek.
To estimate current production, $\mathrm{X}$ equals existing basal area as determined from the inventory. Basal area under the new management equals the basal area left on each portion of the study area under the prescription for that portion. These basal areas are weighted according to the proportional area in each part of the study area, and summed to determine the new herbage production for the study area under the prospective management. The following shows the results of these calculations.

\section{Conclusions}

1. Present herbage production is about 160 pounds per acre per year.

2. Under the new management system, production is expected to increase 135 percent to about 380 pounds per acre per year.

\section{Wildlife Management}

Statement of Concern

Gambel oak is the mast producer of the study area. Maximum mast-producing oak on Beaver Creek have been determined to be 8 to 14 inches d.b.h. with more than 80 percent live crown.

Problem

What is the current abundance and distribution of optimum mast producers, and how 
will this be changed by the proposed management system?

\section{Solution}

The present abundance of optimum mastproducing Gambel oak is determined by entering the stand table for trees with the above characteristics. Abundance following management change is determined by deducting trees to be cut according to the new management prescription. Distribution in each case is estimated by determining the proportion of sampled points occupied by trees of these characteristics at a 25-square-foot basal area level. This distribution is expressed as a percentage of total points. Also, the map (fig. 4) shows that Gambel oak is well distributed over the study area.

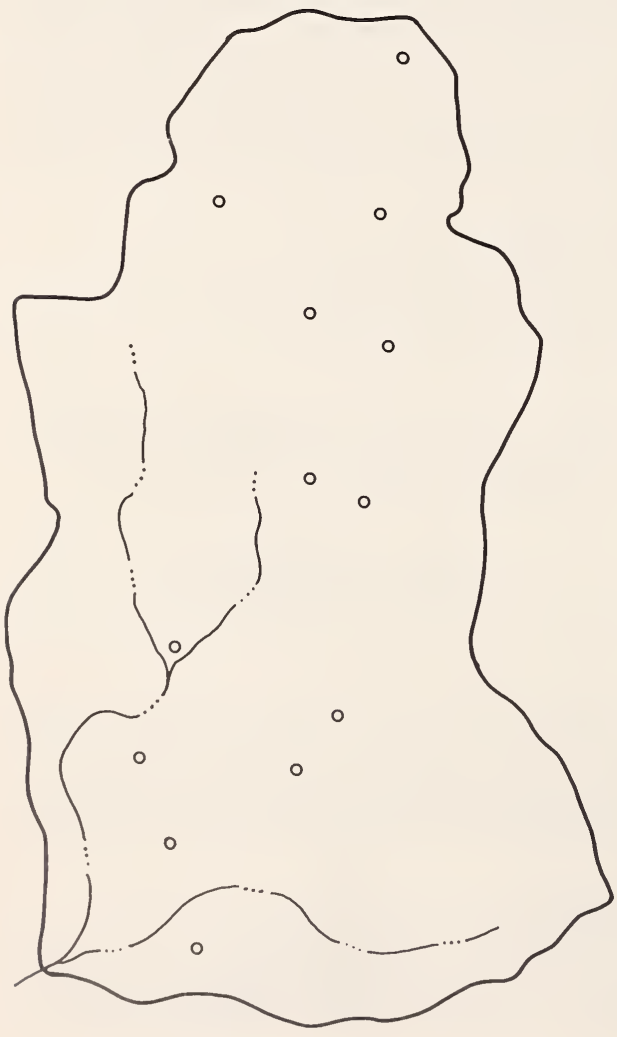

Conclusions

1. Currently, there are 3.8 optimum mastproducing Gambel oak per acre well distributed over the study area. Seven percent of the area is occupied with Gambel oak at a basal area level of 25 square feet per acre or more.

2. After management redirection it is estimated there will be 3.4 trees per acre, and the Gambel oak should occupy 6.2 percent of the area to a basal area criteria of 25 square feet per acre or more.

\section{Recreation Management}

\section{Statement of Concern}

A uniform distribution of medium and large sawtimber trees creates an aesthetic setting for recreation activities. In the absence of definitive information with respect to optimum conditions, a criteria of 10 trees 18 inches and larger per acre has been arbitrarily set as optimum for casual recreation.

\section{Problem}

Estimate the proportion of the area currently supporting 10 trees 18 inches and larger per acre. How will this be changed by incorporating the management system?

\section{Solution}

From the inventory, a stocking equation was developed for trees 18 inches and larger d.b.h. This equation, $\mathrm{Y}=65.3-0.7 \mathrm{X}$, expresses the proportion of the study area currently supporting these trees at different basal area levels. The average diameter of trees in these size classes was determined from the stand table so the basal area level to meet the 10-tree criteria could be computed: 26 square feet per acre. This value of 26 for $\mathrm{X}$ in the stocking equation indicates that 47 percent of

Figure 4.--Distribution of sample points stocked with Gombel oak to basal area of 25 square feet per acre. 
the area is now supporting 10 trees 18 inches d.b.h. and larger.

A map of the spatial distribution of these trees, similar to figure 4 for Gambel oak, revealed that these trees are well distributed over the study area. In the area to be placed under even-aged management, 25 percent of the area is clearcut while the remainder is uncut except for high-risk trees, which do not change the stocking significantly. Stocking under the uneven-aged management system would not meet the specified recreation criteria. The calculations based on these facts predict that only 16 percent of the study area will meet the recreation specifications after management redirection.

\section{Conclusions}

1. Presently 47 percent of the study area meets the stocking requirements for casual recreation.

2. Under the proposed management only 16 percent of this area can be expected to meet this criteria.

\section{COST OF MANAGEMENT CHANGE}

The proposed change in management will cost money, but will also return money from the harvested products. Since the costs are borne by budgeted funds, they must be compared to costs of other projects to help decide on allocations of budgeted funds. Since immediate harvesting returns are divided between the Federal treasury and local counties in lieu of taxes, it is important to anticipate them.

\section{Statement of Concern}

Different forest products marketing arrangements can be expected to affect the costs and returns associated with the management proposal.

\section{Problem}

Estimate costs of clearing and thinning, and returns from the sale of pulpwood and sawtimber stumpage or from sawtimber stumpage alone.

\section{Solution}

1. Costs: Following the timber harvest, 50.6 acres are to be cleared. Typical clearing costs from the project area are about $\$ 50$ per acre. This amounts to a total clearing cost of approximately $\$ 2,530$. Costs following a sawtimber harvest in the absence of a pulpwood market are about $\$ 80$ per acre. Clearing costs in this event would amount to $\$ 4,048$.

The difference between existing and postmanagement stand tables for trees of subcommercial size developed from the inventory give the number of trees to be removed in the thinning operation (table 10).

Table 10.--Existing and postmanagement subcommercial stand table on study area

\begin{tabular}{c|c|c|c}
\hline \multirow{2}{*}{$\begin{array}{c}\text { Diameter } \\
\text { breast } \\
\text { height } \\
\text { (inches) }\end{array}$} & Existing & $\begin{array}{l}\text { Proposed man- } \\
\text { agement level }\end{array}$ & To be removed \\
\cline { 2 - 4 } & \multicolumn{3}{|c}{ Trees per acre } \\
2 & 635 & 42.9 & 592.1 \\
4 & 85.5 & 29.1 & 56.4 \\
6 & 45.3 & 19.6 & 25.7 \\
\multirow{2}{*}{ Total } & 765.8 & 91.6 & 674.2 \\
\hline
\end{tabular}

Current thinning costs from the project area indicate total costs of $\$ 0.018$ per tree. Thinning costs of $\$ 12.14$ per acre are then anticipated, which will give a total thinning cost estimate of $\$ 3,005$ for the 247.5 acres to be put under uneven-aged management. Since there is a question as to whether pulpwoodsize trees can be sold, the additional cost of thinning pulpwood-size trees must also be calculated. Similar stand table comparisons suggest that 250 trees of pulpwood size per acre need to be removed. At a cost of about $\$ 0.06$ each, these larger trees would increase clearing costs by $\$ 15.00$ per acre or $\$ 3,713$ for the study area.

2. Timber harvest returns: Estimated stand tables for the even-aged and uneven-aged 
management areas after the change in management were subtracted from stand tables of existing merchantable-size trees. The difference was multiplied by the volume per tree (Myers 1963) adjusted to net volume from inventory data. These volumes were weighted and summed (table 11).

Table 11.--Merchantable timber volumes to be removed on study area

\begin{tabular}{l|c|c|c|c}
\hline \multirow{2}{*}{ Management area } & \multicolumn{2}{|c|}{ Sawtimber } & \multicolumn{2}{c}{ Pulpwood } \\
\cline { 2 - 5 } & $\begin{array}{l}\text { Average } \\
\text { per acre }\end{array}$ & Total & $\begin{array}{l}\text { Average } \\
\text { per acre }\end{array}$ & Total \\
\hline \multirow{2}{*}{$\begin{array}{l}\text { Even-aged } \\
\text { Uneven-aged }\end{array}$} & 1,430 & 288,800 & 1.81 & 365 \\
\cline { 2 - 5 } Study area total & 1,780 & 450,500 & 1.31 & 324 \\
\cline { 2 - 5 }
\end{tabular}

Exact stumpage prices need to be worked out for each logging chance. An estimate can be made, however, based on typical local prices and market restrictions. Sawtimber offerings of this volume per acre on similar terrain have averaged about $\$ 4$ per thousand board feet. Pulpwood offerings have sold for about $\$ 1$ per cord stumpage. A current pulpwood restriction, however, requires 2 cords per acre be harvested. The expected returns are calculated (1) on the basis of a sawtimber market only, and (2) on the basis of a sawtimber and pulpwood market in case the current pulpwood volume restriction is relaxed. In the first instance, the estimated stumpage return is $\$ 2,957$ for the study area; if the pulpwood market is available the return would be $\$ 3,646$.

\section{Conclusions}

1. The change in management is expected to cost $\$ 5,535$ if pulpwood trees can be sold and $\$ 10,761$ if they can not.

2. Timber harvests associated with the management change are expected to return $\$ 2,957$ if only a sawtimber market is available, or $\$ 3,646$ if both pulpwood and sawtimber markets are present.

\section{A MULTIPLE USE SUMMARY OF THE PROPOSED MANAGEMENT SYSTEM}

An analysis of inventory data by means of research findings shows the proposed management redirection is feasible under the existing conditions on the study area. It will be necessary to convert slowly on the evenaged management area, but the remaining areas can be converted immediately to the required level of uneven-aged management.

The effects of the proposed change in management on the items of concern discussed previously are summarized in table 12. This summary and the supporting calculations contain examples to illustrate the possibilities of the multiple BAF inventory system to provide data for answering multiple use questions. The questions cited and summarized constitute only a small fraction of possible questions.

This method of using research results to analyze and extrapolate inventory information provides quantitative physical data about the effects of a management decision on multiple use production. These data give decision makers one more basis to help decide whether to accept or reject a particular course of action on a specific tract of land.

\section{LITERATURE CITED}

Anderson, Henry W. and Gleason, Clark H.

1959. Logging effects on snow, soil moisture and water losses.* West. Snow Conf. Proc., 27: 57-65.

Ffolliott, Peter F.

1965. Determining growth of ponderosa pine in Arizona by stand projection.* U.S. Forest Serv. Res. Note RM-52, 4 pp., illus. Rocky Mountain Forest and Range Expt. Sta., Ft. Collins, Colo.

Freese, Frank.

1962. Elementary forest sampling. U.S. Dept. Agr. Agr. Handb. 232, 91 pp.

*Address requests for copies to originating office. 
Gevorkiantz, S. A., and Olsen, L. P.

1955. Composite volume tables for timber and their application in the Lake States. U. S. Dept. Agr. Tech. Bul. 1104, 51 pp., illus.

Hawksworth, Frank G.

1961. Dwarfmistletoe of ponderosa pine in the Southwest. U.S. Dept. Agr. Tech. Bul. 1246, 112 pp., illus.

Hoover, Marvin D.

1960. Prospects for affecting the quantity and timing of water yield through snow pack measurement in southern Rocky Mountain area.* West. Snow Conf. Proc., 28: 51-53.

Howell, Joseph, Jr., and Lexen, Bert R.

1939. Fuel wood volume tables for Rocky Mountain red cedar.* U. S. Forest Serv. Southwest. Forest and Range Expt. Sta. Res. Note 68, 4 pp.
Meyer, H. Arthur.

1952. Structure, growth, and drain in balanced uneven-aged forests. Jour. Forestry 50: 85-92.

Myers, Clifford A.

1963. Volume, taper, and related tables for southwestern ponderosa pine。* U.S. Forest Serv. Res. Paper RM-2, 24 pp. Rocky Mountain Forest and Range Expt. Sta., Ft. Collins, Colo.

Pase, Charles P.

1958. Herbage production and composition under immature ponderosa pine stands in the Black Hills. Jour. Range Mangt. 11: 238-243.

Shiue, Cherng-Jiann.

1960. Systematic sampling with multiple random starts. Forest Sci. 6:42-50.

Table 12. --Effect of proposed management system on selected items of concern on study area

\begin{tabular}{|c|c|c|c|c|}
\hline It ems of $\mathrm{s} F$ & pecial concern & $\begin{array}{l}\text { Current } \\
\text { status }\end{array}$ & $\begin{array}{l}\text { Expected will } \\
\text { change to-- }\end{array}$ & $\begin{array}{l}\text { Amount of } \\
\text { change }\end{array}$ \\
\hline \multicolumn{5}{|l|}{ WATERSHED MANAGEMENT: } \\
\hline \multicolumn{4}{|l|}{ TIMBER MANAGEMENT: } & + \\
\hline Timber growth & Cubic feet per acre per year & 33.5 & $\begin{array}{l}\text { Immediately, } 18.3 \\
\text { In } 5 \text { years, } 24.8\end{array}$ & $\begin{array}{r}-15.2 \\
-8.7\end{array}$ \\
\hline \multicolumn{5}{|l|}{ FOREST MANAGEMENT --PATHOLOGY: } \\
\hline Mistletoe incidence & Percent of total trees & 8.3 & 4.1 & -4.2 \\
\hline \multicolumn{5}{|l|}{ RANGE MANAGEMENT: } \\
\hline \multicolumn{5}{|l|}{ WILDLIFE MANAGEMENT: } \\
\hline Mast-producing trees & Number per acre residual & 3.8 & 3.4 & -0.4 \\
\hline $\begin{array}{l}\text { Percent of area stocked with } 5 \text { trees } \\
\text { RECREATION MANAGEMENT: }\end{array}$ & s per acre, at a 25 square-foot basal area level & 7.0 & 6.2 & -0.8 \\
\hline $\begin{array}{l}\text { Stocking of trees } 18 \text { inches } d . b . h \text {. } \\
\text { and larger }\end{array}$ & Percent of area with 10 or more trees per acre & 47 & 16 & -31 \\
\hline \multicolumn{5}{|l|}{ COST OF MANAGEMENT CHANGE: } \\
\hline Budget cost in dollars & With a sawtimber market & 0 & 10,761 & $+10,761$ \\
\hline & With an additional pulpwood market & 0 & 5,530 & $+5,530$ \\
\hline \multicolumn{5}{|l|}{ VALUE OF TIMBER HARVESTED: } \\
\hline Immediate harvest returns & With a sawtimber market & 0 & 2,957 & $+2,957$ \\
\hline in dollars & With an additional pulpwood market & 0 & 3,646 & $+3,646$ \\
\hline
\end{tabular}




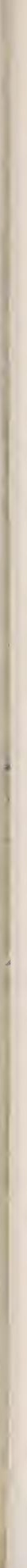




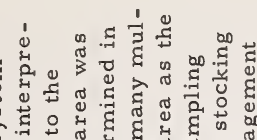

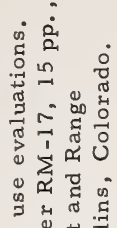

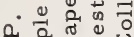

कि

万人

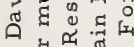

จे

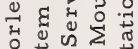

3 in

व की

तี

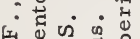

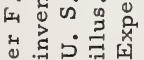

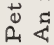

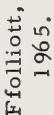

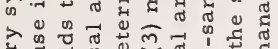

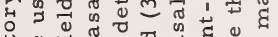

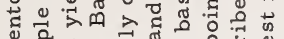

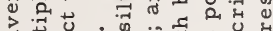

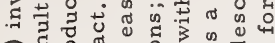

पि द्व

苟 is

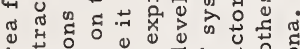

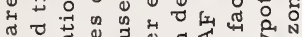

๘

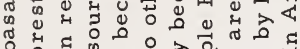

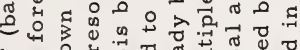

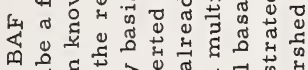

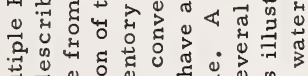

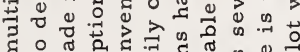

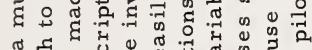

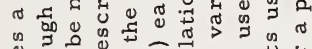

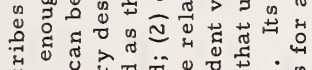

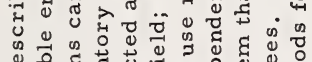

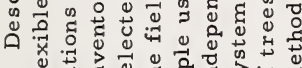

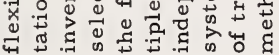

胥

党

西

गें

० $\overline{0}$

उ०

0

a

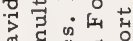

ค็ द्व

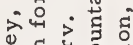

द्य हैं क्ष

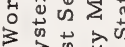

के

त्र त्रे क्ष

新若的的

य

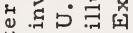

م.

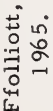

દ

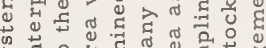

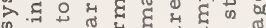
入

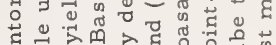
可

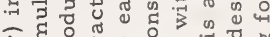

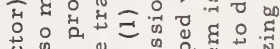
苟 की 世

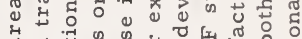

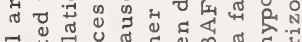
त् กै

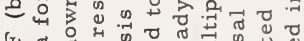

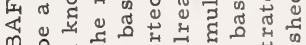

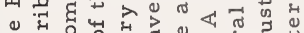

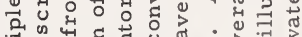

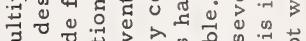
द्व 유 त द्व की द्रु

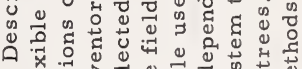

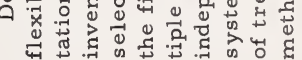

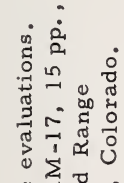

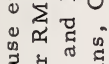

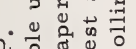

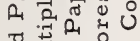

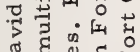

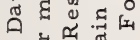

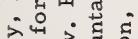

ब द्व

मे

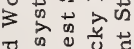

उ के

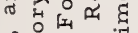

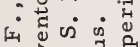

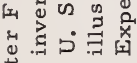

की \&

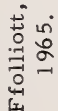

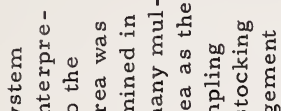
त.

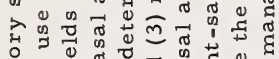

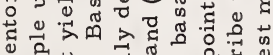

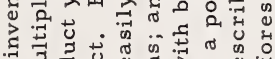
क्ष

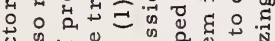

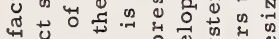
ชु

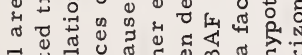

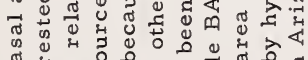
का

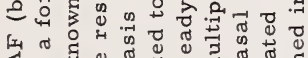
प

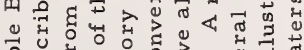

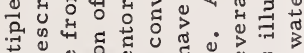
वृ 0 द्व $ᄋ$ द्व ช

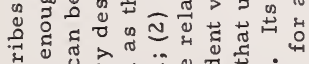
落

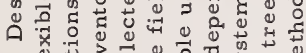

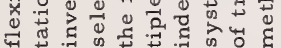

द्य द्वृ

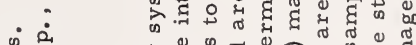

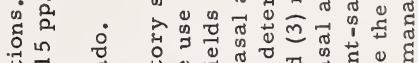

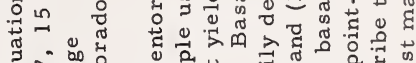

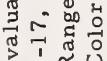

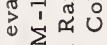
0.

i) 范

ค.

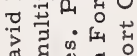

究 हैं 出舟西 बें द्व 罂部 की क्ष त्त त्रें क्ष $\therefore$ 菧的

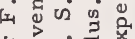

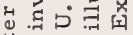
क. द

营

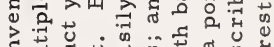

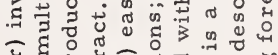
क्ष ह्व पि

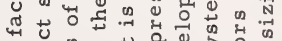

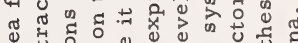
बै సี

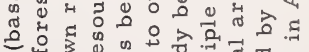
पर

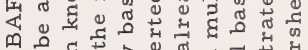
川 ह छ

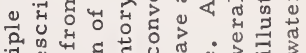

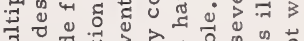
उٓग

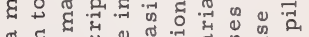
๘ 年

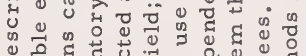
ค न

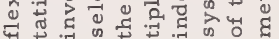


